Accepted for publication in Labor: Studies in the Working-Class History of the Americas (forthcoming 2018). (C) 2017 Christopher Phelps, moral rights of the author have been asserted. No permission to distribute or reproduce without authorization. Draft: Published version will be available in PDF for sale from Duke University Press.

\title{
Heywood Broun, Benjamin Stolberg, and the \\ Politics of American Labor Journalism in the 1920s and 1930s
}

\author{
Christopher Phelps*
}

In the two decades from 1919 to 1939, when labor's fortunes faltered in the Roaring Twenties only to revive in the Great Depression, and when publishers were consolidating the newspaper industry into corporate chains, Heywood Broun (1888-1939) and Benjamin Stolberg (1891-1951) were two of the most prominent American journalists to focus on labor. As first president of the American Newspaper Guild, Broun is the subject of two admiring biographies by fellow journalists who depict him as a gentle, big-hearted, gin-imbibing, lumbering bear of a man, yet his labor writings have received little analysis. ${ }^{1}$ Stolberg, practically forgotten today, was once so admired that the Socialist standard-bearer Norman Thomas placed him "easily in the front rank" of that "little company of those men and women who both understand the American labor movement and can help explain it to itself and to others." ${ }^{2}$ Juxtaposing the lives and writings of Stolberg and Broun will provide insight into American labor journalism's interwar achievements and dilemmas, particularly the politics of its coverage.

\footnotetext{
* The author gratefully acknowledges comments from Tim Barker, Leon Fink, Nelson Lichtenstein, and Jeff Schuhrke, research leave from the University of Nottingham, and the Martin Duberman Visiting Fellowship of the New York Public Library.

${ }^{1}$ Kramer, Heywood Broun; O'Connor, Heywood Broun.

${ }^{2}$ Norman Thomas, undated note, circa 1928, Benjamin Stolberg Papers [hereafter BSP], Rare Book and Manuscript Library, Columbia University, Box 2.
} 
Although journalism is fated to forever fall between the categories of the intellectual and the literary, newspapers had far more impact in the Depression era than the proletarian novels that are the subject of a vaster scholarship. Newsprint was the medium by which Americans made sense of the world in the first half of the twentieth century, when linotype enabled mass production and television did not yet compete for the public's attention. By 1938, there were 2,666 dailies and 12,165 weeklies, with a combined circulation of 38.9 million. Two myths of newspaper work vied then. One was romantic: the dashing correspondent, the smell of printer's ink, the cry of the newsboy. The second was cynical: the hardboiled reporter who rejected "journalist" as a pretentious word, kept a bottle in the bottom desk drawer, and dreamed of writing the Great American Novel while succumbing to hackwork. In actuality, cynicism and glamor commingled in both Broun and Stolberg, who were motivated more by what one newshound called "the compulsion to be where things were happening." ${ }^{3}$

Surprisingly little historical scholarship exists on labor journalism in the 1920 s and 1930s. That which does has had two competing approaches. Drawing on communications theory, one captures narrative frames, as in Troy Rondinone's treatment of how tropes of strikes as war inculcated biases against labor. The other focuses on the intentionality of individual journalists, as in David Witwer's exposition of how ideals of objectivity and balance enabled New York Times reporter Louis Stark to subtly promote labor's growth, in contrast to columnists Westbrook Pegler and Victor Riesel and their obsessions with union corruption and Communism. This essay augments each of these approaches. It focuses on two journalists who wrote for the commercial press but flaunted negative framings of labor news and disavowed "impartiality," cultivating instead a journalistic ethos of political engagement and bold conveyance of truth as they saw it. ${ }^{4}$

While they never spent much time together, Broun and Stolberg had much in common. Each spent years at Harvard never to receive a degree. Each lived in New York and wrote for Pulitzer's World,

\footnotetext{
${ }^{3}$ Harris, American Labor, 186; Stewart, News is What We Make It, 7.

${ }^{4}$ Rondinone, The Great Industrial War; Witwer, "The Heyday of the Labor Beat."
} 
The Nation, and the Scripps-Howard chain. Each was drawn to the Socialist Party and moved leftward beyond it. Each was witty and charming but prone to melancholia. Each was a "newspaperman" in an era when a gendered term could be applied universally, yet each married strong, independent women who kept their names, only to see the marriage end in divorce. Each was prolific despite ambivalence toward work. Each began to cover labor and class in the twenties, before those topics were in vogue. Each wrote in a period when American liberals, radicals, and progressives put labor at the core of their projects. Accordingly, each found an audience while portraying unions sympathetically despite a context in which, as New Deal cabinet member Harold Ickes wrote, "by and large the press is unfriendly to organized labor." ${ }^{5}$

Yet these two journalists were also very different-opposites, even. Labor was Stolberg's purview from the outset; only in midlife did Broun take it up. A bemused skeptic, Stolberg could be either irascible or sparkling; Broun was approval-seeking, affable, an enthusiast and joiner. Broun's humor entailed genial self-deprecation and humane bemusement; Stolberg's was sardonic. In the 1930s they held opposed views of the Communist Party and Soviet Union; Broun emerged as the quintessential Popular Front fellow-traveler while Stolberg hewed to an uncompromising anti-Stalinism. Consequently, they surveyed the Congress of Industrial Organizations $(\mathrm{CIO})$ from irreconcilable viewpoints. When at last Broun and Stolberg crossed paths, they crossed swords.

\section{Two Pathways to Harvard and the Newspapers}

The contrasting boyhood experiences of Heywood Broun and Benjamin Stolberg suggest familial origins for their differences in personality, with circumstances leaving Stolberg insecure and sustaining Broun's easygoingness. Stolberg was raised in Munich, Bavaria, the son of Ukrainian-Jewish émigrés Frada (or "Rada") and Michael Stolberg. His parents' outward decorum masked a chilly estrangement.

\footnotetext{
${ }^{5}$ Ickes, America's House of Lords, 85.
} 
When Stolberg was a boy, they divorced and his mother left to return to Russia. His father, an owner of Russian sugar refineries, remarried and had more children. The Munich home was visited by social democrats, artists, and Russian revolutionaries, while the Rëal-Gymnasium provided Stolberg "a strange amalgam of Athenian free learning and skepticism with Spartan 'discipline' and brutality." When he was 16 , in 1908, Stolberg and several classmates visited "a cabaret which really was a place of prostitution." His father-always a remote, anxiety-inducing figure-then informed him he was adopted as a baby, so had no claim on the family fortune. Considering himself orphaned, Stolberg set out alone for America. ${ }^{6}$ Initially, Stolberg lived with relatives in St. Louis, Missouri, studying medicine at Washington University before withdrawing. ${ }^{7}$ During the ensuing five years, he recalled, "I sold papers, shined shoes, tended bar, ....worked as a common laborer, a lunch counter man, did all sorts of things. For weeks at a time I was out of work, went hungry, slept on park benches. And for about half a year I traveled all over the country...making a sort of Hobo Grand Tour of our continent." ${ }^{8}$ In 1914, at 23, he entered Harvard, studying philosophy while working in Boston eight hours a day at a municipal lodging house for homeless men. His marks were spotty and failure to pay tuition meant he was not awarded a degree after more than three years of study. A letter placed in his file by the Dean in 1921 advised against ever granting the B.A. to "a man who made his washwoman wait more than fifteen months for her pay." This condemnation of character may have been just-Stolberg did not meet his financial obligations at university-but probably also reflected the class condescension and anti-Semitism then at their Ivy League apex. ${ }^{9}$

\footnotetext{
${ }^{6}$ Stolberg to Fred T. Marsh, March 8, 1945, BSP, Box 4a, Folder D3; autobiographical fragments, BSP, Box 11; Stolberg Social Security application, September 1950, ancestry.com.

${ }^{7}$ An unpublished essay by Stolberg's granddaughter says his son recalled that a professor bade Stolberg leave Washington University when he spotted three testicles on a cadaver, an observation deemed indecent: Mary M. Stolberg, "No Man is an Orphan." Only attendance dates of 1909-10 can be corroborated: Sue Hosack, Washington University Registrar, e-mail to author, September 21, 2016.

${ }^{8}$ Stolberg to Fred T. Marsh, March 8, 1945, BSP Box 4a, Folder D3.

${ }^{9}$ Benjamin Stolberg card [n.d.] and Henry A. Yeomans memorandum, February 18, 1921, Harvard University Archives.
} 
By comparison, the early life of Heywood Campbell Broun, whose surname rhymed with "noon," seems carefree. His father Heywood Cox Broun was an Englishman of Scottish descent and Wall Street brokerage manager who observed a daily cocktail hour. ${ }^{10}$ The family inhabited an Upper West Side Manhattan brownstone, his mother dressing her boy in short pants, his hair tumbling down in ringlets. He was sent to the elite private Horace Mann School. ${ }^{11}$ At Harvard, Broun was part of the illustrious class of 1910, which included poet T. S. Eliot and future journalists John Reed, Stuart Chase, and Walter Lippmann. At Lippmann's invitation, he joined the Socialist Club, although later he would claim that his radicalism owed more to conservative economics professor Thomas N. Carver. Carver would present radical panaceas in autumn by hosting speakers of anarchist, socialist, syndicalist, and single-tax persuasion, then demolish their arguments in spring, according to Broun. When one spring afternoon in 1908 Broun stole away to watch the Boston Red Sox, outfielder Tris Speaker hit a home run, two triples, and a double, and made a catch "by sliding the last twenty feet on his stomach." The effect was electric: "Professor Carver couldn't do that." So Broun skipped spring classes: "I just went completely laissez-faire and never missed any of the remaining games. The arguments for the radical theories I had heard, but I never got round to hearing the answers."12

That anecdote, pitch-perfect for the New Republic in 1937, was reproduced with relish by Broun's biographers, but it was a fable. Broun's transcript shows he took Economics in 1908-09, not the prior year, received a $D$ in autumn, was admonished for cutting class, then obtained a B in spring. Not only did he performed better in baseball season, but the course catalogue shows Carver covered "The Distribution of Wealth" in fall, and "Methods of Social Reform—Socialism, Communism, the Single Tax, etc." in spring, reversing Broun's recollection. It was neither the first nor last time Broun would take

\footnotetext{
${ }^{10}$ Broun, Collected Edition, 244-45; New York Times, August 29, 1930.

${ }^{11}$ O'Connor, Heywood Broun, 17-18.

${ }^{12}$ Broun, Collected Edition, 405-406.
} 
poetic license; his journalism was always imaginative. The story did convey this essential truth: Broun was an erratic student. Failing final-year French, he never graduated from Harvard. ${ }^{13}$

One summer, Broun became a cub reporter with the New York Morning Telegraph, a sheet devoted to horse racing and vaudeville whose managing editor his father knew. "Very often you couldn't get to your desk," he reminisced, "because there would be a couple of chorus girls sitting there waiting for a friend who was finishing an editorial." ${ }^{14}$ After Harvard, he stayed on at the Telegraph until 1909, when he was fired for asking for a raise. Half a year later, at 23, he was hired by the Tribune, a posh Republican paper where legends still lingered of Horace Greeley's reformism. A copyreader, Broun wrote book and theatre reviews, graduating to rewrite, where his talent for amusing phrases made him a magnet for items desiring a light touch. Tapped as sportswriter, he covered the Giants in the 1911 World Series with flair, eventuating in his first byline, then a rarity, by 1914 . Promoted to sports editor, he found he had no talent for management; he was haphazard in laying out the sports page and let writers name their own salaries. Instead Broun took up drama criticism, encouraged by Ruth Hale, a southern suffragist and journalist whom he married in 1917 just before they left for France to cover the First World War. After the war, as Tribune literary and drama editor, Broun wrote a thrice-weekly books column that morphed into his true calling when, having not read a book one afternoon, he dashed off a piece about his dog, followed the next week by one on his baby boy. From then on, Broun wrote about his life-particularly the shenanigans of "H. 3d" (Heywood the Third). By folding in reflections on affairs of the day, Broun came to invent the modern opinion column running parallel to, even against, the newspaper's own editorial position. ${ }^{15}$

In Stolberg's career, it was labor journalism from the outset, conceived as a way of thinking through social problems. In 1919-20, he spent a year as a sociology graduate student at the University of

\footnotetext{
${ }^{13}$ Heywood Broun card, Harvard University Archives; Harvard University Catalogue, 1908-1909.

${ }^{14}$ Broun, Collected Edition, 4.

${ }^{15}$ Kramer, Heywood Broun, 102.
} 
Chicago as the city roiled with strikes and race riots. ${ }^{16}$ Residing at Hull House, he admired Jane Addams's vigor on child labor, the minimum wage, and women workers. ${ }^{17}$ The First World War's outcome in the Russian Revolution riveted him. "The old autocratic, frankly imperialistic Germany is dead, and over its grave struggles the social revolution born of its Russian prototype," he wrote in the Chicago Evening Post in February 1919. "The war of the nations carried in it the germs of the red war of the classes." ${ }^{18}$ In 1919 and 1920, Stolberg taught six-week sociology courses for the Red Cross Home Service at the universities of Oklahoma and Kansas. At the invitation of E. J. Costello, editor of Victor Berger's Socialist Milwaukee Leader, he joined with Louis Lochner and Carroll Binder, his old Harvard roommate, to organize the Federated Press, a labor news service. The Federated Press occasioned Stolberg's first major reporting feat: a series on Kansas's new industrial court for which he interviewed Republican Gov. Henry Allen for more than an hour, remarking on his "bull-like aversion to all things red, an aversion so delicately sensitive that he can discern it even in an ordinary demand for a living wage." Stolberg judged the industrial court a captive of corporate interests but was impressed by the defiance shown by the United Mine Workers of America (UMWA) in Pittsburg, Kansas, under district leader Alexander Howat. "When the snubbed 'court' tried to force itself into recognition by having the district court arrest their leaders," he reported, "the men just struck and chewed the rag around the corners and played pool and took their kids to the movies and had a general good time, until the district court released their leaders. Then the 12,000 miners went back to work." ${ }^{19}$

Stolberg's next destination was Cleveland, Ohio, where for a time he helped staff the Locomotive Firemen's and Engineman's Journal, circulation 150,000. Never again would he accept a position with an official union publication, or what he termed "a labor press for which dull stupidity has

\footnotetext{
${ }^{16}$ Stolberg transcript, University of Chicago.

${ }^{17}$ Stolberg, "The Shake-Up of the World Is Rousing Women to Action."

${ }^{18}$ Stolberg, "Prof. Kallen on Class Warfare."

${ }^{19}$ Stolberg, "The Kansas Industrial Court."
} 
no equal." ${ }^{20}$ The position did enable him to freelance for national publications in 1922 on the railway shop strike, which historian Irving Bernstein calls "the greatest strike of the decade." Diligently, Stolberg visited strike headquarters daily for months, talked to railroad executives, and interviewed Railroad Labor Board members. "The strike was lost in as far as it was not a complete victory," he wrote, "because the public was indifferent and the Harding administration was weak towards both sides and hostile to the shopmen. But above all, the strike was lost, because craft unionism can no longer protect the worker, especially in a basic industry." ${ }^{21}$

\section{The Fish Peddler, the Factory Hand, and the Speakeasy Columnist}

In 1921, Heywood Broun vacated the Tribune for the New York World, the liberal daily founded by Joseph Pulitzer that in the twenties attracted talent including Ring Lardner, E. B. White, and Walter Lippmann. There his column debuted as "It Seems to Me," which it was called forever after. Syndication eventually gave Broun an audience of millions and income of more than $\$ 70,000$ ( $\$ 1$ million today), forty times what most reporters made. ${ }^{22}$ The success was not his alone, for Ruth Hale wrote items under his name-his rates were higher-even while launching a Lucy Stone League to advocate that married women retain their own names. When she died in 1935, a few years after their divorce, Broun praised her as "the better newspaperman of the two," his "severest critic" and "best friend," and told others she was the one who talked newspaper unionism to him year after year, until it sunk in. ${ }^{23}$ Manhattan's Prohibition-era nightlife was Broun's playground. He often stayed out until dawn, picking up his table's tab at the Stork Club or Jack and Charlie's 21 Club, or regaling young women as permitted by his "modern" marriage, one reason he and Hale established separate Manhattan apartments. He was a regular of the Algonquin Round Table, the famed circle of lunchtime wits that included New Yorker

\footnotetext{
${ }^{20}$ Stolberg in Laidler and Thomas, New Tactics in Social Conflict, 59.

${ }^{21}$ Bernstein, The Lean Years, 211; Stolberg, "The Great Stupidity," 21.

22 Ernst, The Best is Yet, 42.

${ }^{23}$ Broun, Collected Edition, 218-219, 324-325; Seldes, Witness to a Century, 62.
} 
editor Harold Ross and writer Dorothy Parker, and he presided over a perpetual high-stakes card game, "The Thanatopsis Literary and Inside Straight Poker Club." ${ }^{24}$

Beneath the bonhomie lay vulnerabilities. One of Broun's closest friends, the civil-libertarian attorney Morris L. Ernst, who caroused with him for years, saw Broun as "gay but seldom happy," plagued by phobias of crowds and death, governed by a "desire for certainty," and wanting "friendship more than anything else on earth," a man who "never could organize his own life" and spent more than $\$ 70,000$ on psychiatrists and psychoanalysts. ${ }^{25}$ Trivial tales about trying to land a bullhead in the pond at his Connecticut farm were typical fare for Broun's column, but he tested more serious boundaries as early as 1924 by blasting William Jennings Bryan for opposing a Democratic Party resolution to condemn the Ku Klux Klan. In 1926, Socialist Eugene V. Debs's death brought a glowing tribute. "It gives me a swift pain to go around to meetings and have people call me 'comrade,' " Broun wrote, but Debs really meant it. "The Debs idea will not die... It will come to pass. There can be a brotherhood of man." ${ }^{26}$

His real swing toward labor and class came with two 1927 columns on Nicola Sacco and Bartolomeo Vanzetti, Italian immigrants convicted for armed robbery and murder in Boston. "It took a major national tragedy," Broun later remarked, "to animate me to any major purpose." Under Lippmann, who had passed from socialism to liberalism en route to conservatism, the editorial page of the World proposed that the sentence be commuted to imprisonment, but Broun sought a pardon or new trial. He inveighed against Harvard president Abbott Lawrence Lowell, who declared the proceedings fair: "It is not every prisoner who has a President of Harvard University throw on the switch for him. If this is a lynching, at least the fish peddler and his friend the factory hand may take unction to their souls that they will die at the hands of men in dinner coats or academic gowns, according to the conventionalities required by the hour of execution." The following day came a second salvo: "From

\footnotetext{
${ }^{24}$ Adams, "Comrade Broun," 341.

${ }^{25}$ Ernst, The Best is Yet, 75.

${ }^{26}$ Broun, Collected Edition, 180-183.
} 
now on, I want to know, will the institution of learning in Cambridge which once we called Harvard be known as Hangman's House?" On August 12, 1927, Ralph Pulitzer, son of the paper's founder, announced that Broun had been allowed to express his views with "utmost extravagance," was told to find other subjects, but kept submitting Sacco-Vanzetti material, so the World, "exercising its right of final decision as to what it will publish in its columns, has omitted all articles submitted by Mr. Broun." A standoff ensued as Broun refused to write for the World but was contractually forbidden to work for other papers, leaving him confined to magazines. In "The Rabbit that Bit the Bulldog," a pseudonymous self-satire in the New Yorker, Broun pictured himself as a "crusader riding out to do battle even though he dreads it." Broun returned to the World in January 1928, much admired for his stand, but trouble flared again when he wrote in The Nation that despite aspiring to match the Manchester Guardian's liberalism, the World takes "two, three, or even four different stands" on any issue, lending doubt to claims of its "courage or tenacity." Pulitzer fired him-Broun suspecting it Lippmann's doing. ${ }^{27}$

"It Seems to Me" promptly found a home with the New York Telegram, a paper recently acquired by Scripps-Howard. Originating in Ohio in the 1890 s as the first newspaper chain, its papers had a liberal reputation of fighting for the underdog and labor, those who founder E. W. Scripps called "the 95 percent," boosting their mass circulation. ${ }^{28}$ At the Telegram, Broun's syndication success continued-and his commitment to labor deepened. Once again displaying chivalry toward victims of his alma mater, Broun in 1930 condemned Harvard's discharge of "twenty scrubwomen rather than raise their wages." One, he wrote, had "done rather more to tidy up the place than even A. Lawrence Lowell himself. She left no dark and clotted stains behind her." While Broun still loved the nightlife, his columns-whimsical but suffused by an ethic of fairness-were increasingly class-conscious. In 1930, he cited the Gastonia, North Carolina, textile strike as evidence of why journalism ought to "get at the root

\footnotetext{
${ }^{27}$ Broun, Collected Edition, 445, 198, 204-205, 216, 220-221; Ernst, The Best is Yet, 74.

${ }^{28}$ Stark, "The Press and Labor News," 108.
} 
of conditions which underlie strife and prejudice and turmoil," and the following year he censured the American Red Cross for not aiding "the starving children of striking Pennsylvania coal miners." 29

\section{Interpreting Labor's New Era}

One Sunday in 1923, Benjamin Stolberg's byline appeared in the World over parallel profiles of two distinctive labor leaders: Samuel Gompers, founder of the American Federation of Labor (AFL), and William Z. Foster, radical leader of the 1919 steel strike. Gompers was credited for his tactical wiles and success in forging a lasting labor federation, but his histrionics at mere mention of his union critics were divulged: "There was tremendous force as his fist came down, his mouth and eyes contracted, his stocky frame literally shaking with righteous indignation." As for Foster, Stolberg admired his view that craft unions should amalgamate and radicals stop separating off in dual unions, as had the Industrial Workers of the World. Could Foster carry it off, though? "On a recent trip through our basic labor centers I found that Foster's propaganda had been more effective than I had expected. ...There is no doubt that he is accelerating the concerted movement in American labor. But he may find that his recent open alliance with the Communists... will drive him so far to the left of the American workers that he will have manoeuvred himself into another secession movement." ${ }^{30}$

Those profiles show why Stolberg was the more serious labor journalist in the 1920s than Broun: he wrote on it earlier, more consistently, and with more knowledge. It was an unpropitious moment to make labor one's beat, given the open-shop drive and company unionism that left labor "utterly deflated" just as American capitalism attained a "cohesive syndicate of powerful vertical trusts at home and a world-creditor empire abroad." ${ }^{31}$ Still, Stolberg's work stood out for its detail and insight, qualities on display in a 1922 article on coal unionism for The Nation in which he described the miner as "our

\footnotetext{
${ }^{29}$ Broun, Collected Edition, 239; Broun, It Seems to Me, 146.

${ }^{30}$ Stolberg, "Diverging Paths on Labor's Highway."

${ }^{31}$ Stolberg, "The Predicament of American Labor," 351; Stolberg in Laidler and Thomas, New Tactics in Social Conflict, 54-55.
} 
most radical worker" who lives in the "seclusion of the mining camp" working in "weird darkness and quiet and monotonous toil" while mineworkers' union leaders were "conservative" from their "state of constant and detailed administrative brokerage with Big Capital, for coal is interlocked with railroads and New York finance." Stolberg's stylistic gifts were in evidence in his depiction of the UMWA leader who would dominate labor in the following decade: "There is a touch of anthracite about John Lewis. He is hard and smooth and burns with difficulty, but with a steady flame." 32

It is insufficiently appreciated that the industrial union sensibility that would prevail in the 1930s was seeded by a small number of labor journalists in the 1920s including Stolberg, who criticized craft parochialism unflaggingly. In covering the railroad strike of 1922, he faulted "our craft-bourgeoisie" in the four railroad brotherhoods (engineers, firemen, trainmen, and conductors) for not uniting with the dozen shop unions. ${ }^{33}$ The trainman president told him that "industrial unionism is a dream, impossible of realization," but to Stolberg craft separatism was the impracticality. ${ }^{34}$ In the booming auto industry, he noted, "Ford and the General Motors do not employ craftsmen but human automata which are practically unorganizable under the A. F. of L. structure." ${ }^{35}$ Stolberg faulted the AFL for being "petty, impotent, ignorant, and frequently corrupt, because its philosophy is to be a job trust" whereas "a labor movement is alive to the degree to which it is impregnated with a social-democratic drive." ${ }^{\prime 36}$ As for the "trade-union capitalism" of the New Era, "profit-seeking investments" in labor banks and real estate, Stolberg thought that akin to "collaboration with management in the shop." A better answer, he held, lay in organizing the unorganized, putting solidarity above jurisdictional disputes, and pressing for higher standards of living: "If labor compromises in its fundamental militant protectiveness of the worker, it

\footnotetext{
32 Stolberg, "The Tragedy of Coal," 336.

33 Stolberg, "Railroad Labor Amalgamation," 339.

34 Stolberg, "Railroad Labor's Tendencies."

${ }^{35}$ Stolberg, "William Green's Convention," 450.

${ }^{36}$ Stolberg, "Beginning the Great Change in Industry."
} 
merely deteriorates into a form of dues-paying self-liquidation. ${ }^{\prime 37}$ Despite this perspective's power, it did not prevent Stolberg from making mistakes. In 1925, he heralded new AFL head William Green as a "progressive" who would bring "The End of the Gompers Tradition" since he emerged out of the mineworkers, an industrial union with a militant history. As Green's craft compromising became plain, Stolberg was soon faulting him for speaking to chambers of commerce more often than labor. ${ }^{38}$

Disdainful of "hesitancy of courage disguised as impartiality," Stolberg was fiercely independent, professionally and politically. ${ }^{39}$ After moving to New York in 1923, he spent a year as a Sunday World feature writer. He sometimes worked out of Oswald Garrison Villard's The Nation at 20 Vesey Street. Mostly, though, he was a freelancer who believed that "of all the major professions in this country journalism is still the least free." ${ }^{40}$ Politically, he was close to the Socialist Party, endorsing Norman Thomas for President in 1928, but he orientated toward a broader labor left. As New York League for Industrial Democracy (LID) president in 1929 he chaired a forum with A. J. Muste, Morris Hillquit, and John Dewey to protest Brookwood Labor College's banishment from the AFL's workers' education program. ${ }^{41}$

Stolberg's intrepidity, like his mockery, was connected to his youthful necessity of fending for himself. "Deep in him," wrote his friend Louis Adamic, "he was an individualist." ${ }^{42}$ A girlfriend from his Chicago days characterized him as "tortured in spirit, so lonely at times, so dependent," but endowed with the Romantic poet Shelley's "fiery soul and sensitive spirit-and inability to adjust himself to a stupid civilization, or rather age." ${ }^{43}$ In 1925, Stolberg married Mary Fox, a Vassar graduate and schoolteacher who became the LID's executive secretary; they had a son, David, but were divorced in

\footnotetext{
${ }^{37}$ Stolberg, "The New Unionism," 292, 295.

38 Stolberg, "The End of the Gompers Tradition," 186-187; "Immigrant Called Valuable to Labor," Dallas Morning News, December 21, 1928; “Calls Baldwin Thorn in Mill Strike in N.C.," Baltimore Sun, November 18, 1929.

${ }^{39}$ Stolberg, "The Revolt in the Unions," 743.

${ }^{40}$ Stolberg, "A Great Journalist."

${ }^{41}$ Scrapbook, BSP, Flat Box 575.

${ }^{42}$ Adamic, My America, 73.

${ }^{43}$ Edna [surname unknown] to Benjamin Stolberg, January 21, 1925, BSP Box 8, Folder S1; “Mary Herling, a Leader in Community Activities," New York Times, November 7, 1978.
} 
1929 following "acts of mental cruelty." ${ }^{\prime 4}$ This legal boilerplate from the era of constricted divorce may allude to Stolberg's lifelong inability to hew to monogamy. His parting letter showed tenderness and self-reproach: "Thank you, Mary, for having loved me so well and tragically and so courageously. You have tried so hard! ...You are the loveliest person I ever knew." ${ }^{45}$ Adamic, who knew him best in the early thirties, described Stolberg as "a small, delicately made, agile, blond man, with a deep, pleasant voice, a friendly manner and generally charming personality, illumined every other moment as he spoke by flashings of his scintillating mind," but saw in him "a deep and complex sadness," a man "erratic, bitter, at odds within himself." ${ }^{46}$ He was also, however, the type of person willing to go out of his way to aid the Brotherhood of Sleeping Car Porters in its infancy, hosting a fundraiser and penning a 1926 article in The Nation hailing "the first significant attempt to organize the colored worker-on a job whose very picturesqueness, popularity, and ubiquitousness render it strategic." In a personal letter praising Stolberg for his "fine spirit of cooperation," A. Philip Randolph wrote, "Say, Ben, I didn't know that you have such a happy and delicious view of humor, as flashed out in the meeting Monday night." ${ }^{47}$

Long before most, Stolberg comprehended the newsworthiness of the Communist presence in American labor. He himself was so left-wing that when he went out drinking with John J. Leary, Jr., the World's labor reporter, a Gompersite close to Green, "we would have a helluva row" as Leary lambasted Stolberg together with other "reds and socialists and so on." ${ }^{48}$ Be that as it may, Stolberg did not consider the Soviet experiment transferable. The "Bolshephobia" of 1919's Red Scare reflected a failure to perceive the "profound difference between Russia and America," he wrote; Communists replicated the error by hitching themselves to "an international movement whose political game is played out

\footnotetext{
${ }^{44}$ Agreement, February 18, 1929, BSP Box 4, Folder C2.

${ }^{45}$ Benjamin Stolberg to Mary Fox, October 26, 1929, Box 8, Folder S1.

${ }^{46}$ Adamic, My America, 72, 329.

47 Stolberg, "The Pullman Peon," 367; Randolph to Stolberg, May 27, 1926, BSP Box 2.

48 "Reminiscences of Benjamin Stolberg," July 31, 1950, Columbia Center for Oral History, New York [Hereafter "Reminiscences"].
} 
6,000 miles away." ${ }^{49}$ In two New York Times articles in 1925 and 1926, Stolberg held that Communists and their labor supporters worldwide "are subject to the political exigencies of the Soviet State." ${ }^{50}$ (Never again would he write for the Times, likely because in his 1926 Atlantic profile of publisher Adolph S. Ochs called him a "congenital conformist" with a "simple recipe of life" that "never challenges the established order." ${ }^{51}$ )

Words of respect could still be exchanged across radical factional lines in the twenties. Stolberg complimented Earl Browder for his "native good sense." In Hearst's International, he proclaimed Foster "the most outstanding radical figure in our contemporary labor movement," approving of the Trade Union Educational League's program even while lamenting Communist "revolutionary antics." Browder returned suit in the Daily Worker, saying that "Brother Ben" was "amusing and entertaining" with "a superficial keenness in observing facts," but classed him among the "progressive talkers" writing for "capitalist or liberal newspapers and magazines." 52

Soon mixed assessment gave way to condemnation on both sides. Stolberg came to think the Communists were "irresponsibly disruptive." ${ }^{53}$ Early in the twenties, he wrote, they formed oppositional factions in the mineworkers and needle trades although those unions were organized industrially. In 1924, they split the Farmer-Labor Party, alienating John Fitzpatrick of the Chicago Federation of Labor and causing "irreparable damage to the American labor movement by driving all the liberals and progressives in it under the cover of the official hierarchy." ${ }^{14}$ Finally, they acted as "left-wing wreckers" in the garment industry. ${ }^{55}$ In that sector, the unions Stolberg most admired were the International Ladies' Garment Workers Union (ILGWU) and Amalgamated Clothing Workers, viewed by him as

\footnotetext{
49 Stolberg, "The Peter Pans of Communism," 221; Stolberg, "The Vagaries of Communism," 205-206.

50 Stolberg, "Labor Action Varies in Different Lands."

51 Stolberg, "The Man Behind the 'Times,'" 721-722, 730-731.

52 Stolberg, "Peter Pans of Communism," 224; Stolberg, "The Mouse That Frightens Hughes," 160; Stolberg, "The Vagaries of Communism," 205, 207; Browder, "The Predicament of 'American Intellectuals"”; Browder, "Our Timid Progressives," 50-51; Browder, "Workers' Education-or Mis-Education?" 142.

53 Stolberg, "The Predicament of American Labor," 351.

${ }^{54}$ Stolberg, "The Mouse That Frightens Hughes," 160.

${ }^{55}$ Stolberg, "Pot Calls the Kettle Black," 4.
} 
paragons of social democracy; Sidney Hillman's Amalgamated, for example, he praised for advocating "day nurseries, where working mothers...might leave their children during working hours." ${ }^{56}$ In 1926, Stolberg watched bitterly as the ILGWU was almost destroyed when Communists provoked an expensive, disastrous 28-week strike. "Never in the history of American labor," he wrote in a three-part series for The Nation, "has a strike been more incompetently, irresponsibly, and wastefully managed." ${ }^{57}$ Stolberg faulted the ILGWU for expelling Communists, but the Daily Worker, by then in its Third Period phase of attacking all others on the left as counter-revolutionary, denigrated Stolberg as "ingratiating, sly, mercenary." ${ }^{58}$ The garment debacle left an indelible impression: Stolberg entered the Depression an adversary of capitalism and Communism in equal measure.

\section{Appraising the Early New Deal}

In the years following the 1929 crash, Stolberg and Broun, entering their forties, diverged in mood. Even as the Depression radicalized him, Stolberg fell into a pessimistic gloom. "Our dominant labor movement is spiritually too bankrupt to learn anything," he wrote. ${ }^{59}$ Retaining his objection to the Communist Party as tied to "exigencies of Russian internal and foreign policy," Stolberg was increasingly jaundiced about "the YMCA Socialism of Norman Thomas" as well, seeing "no authentic and indigenous revolutionary party in the United States, nor even one in the process of formation." ${ }^{60}$ As he pulled back from labor journalism into book criticism on The Bookman in 1928-1929 and New York Evening Post in 1932-1933, his friends the novelist Sinclair Lewis and columnist Dorothy Thompson might still express a desire for "the stimulation of your bright wit," he might organize a Writers' League against Lynching, and

\footnotetext{
${ }^{56}$ Stolberg, "The Vanguard," 269.

${ }^{57}$ Stolberg, "The Collapse of the Needle Trades," 498-499. Stolberg's view of the 1926 strike is echoed by historians and participants: Bernstein, The Lean Years, 138; Parmet, The Master of Seventh Avenue, 49-50; Gitlow, I Confess, 357-63; Dubinsky and Raskin, David Dubinsky: A Life with Labor, 84-117.

${ }^{58}$ Garlin, "Fake 'Progressives.' "

59 Stolberg, "The Tailor and the Scientific Method," 668.

60 Stolberg, "Morris Hillquit," 122; Stolberg, "Votes Won't Do It!" 11-12.
} 
he might attend monthly German beer-hall dinners organized by the radical Modern Monthly editor V. F.

Calverton, but it is little wonder his close friend Abram Harris, a Howard University economist, confessed to being "a little worried...about your periodic moments of despair." ${ }^{61}$

Setting out in a remarkably different can-do spirit to stem mass unemployment on his own, Broun launched a "Give a Job Till June" campaign in 1930, but for every opportunity identified came a hundred jobseekers. Next he produced "Shoot the Works," a show to put the theatrical arts back to work in which he himself danced and sang in what the New Republic termed a "baby-elephantine" performance. ${ }^{62}$ These quixotic efforts helped Broun appreciate the need for federal action-and introduced him to his second wife, dancer Connie Madison. In 1930 and 1932, he ran for Congress as a Socialist in the Upper East Side "Silk Stocking District," advocating national unemployment insurance. Still a dilettante, he arrived on the hustings in a limousine, took belts from a silver gin flask, and quipped, “Roosevelt can't lose. Hoover can't win. Why throw away your vote?" ${ }^{63}$ Attending the 1932 Socialist convention in Milwaukee, he supported a "confiscation" resolution, its defeat signifying to him that "the Socialist Party in America is not a radical party at all." ${ }^{64}$ Until then Broun mocked "Stalin's stooges," the Communists: "No sect in the country rides to hounds after the poor heretic with more enthusiasm. It is a stirring sight on a crisp morning to see the gentlemen and ladies in their red coats tally-hoeing the Trotskyite over hill and dale. ${ }^{\prime 65}$ But when the Communists made a cause célèbre of the rape frame-up of nine young African-American men in Scottsboro, Alabama, he thought it revealed a national injustice: "The South imposes rather more lynchings, legal and otherwise. New York and Chicago take it out in tuberculosis." ${ }^{\prime 66}$ When he began to address Communist-sponsored meetings for the Scottsboro Boys and

\footnotetext{
${ }^{61}$ Thompson to Stolberg, July 31, 1935, BSP Box 2; Harris to Stolberg, December 8, 1933, BSP Box 4 b, Folder H3.

62 "Friendly Novices," New Republic, August 5, 1931: 317.

63 "It Seems to Me," World-Telegram, September 19, 1932.

${ }^{64}$ Broun, "All Quiet Along the Rubicon," 4.

65 "It Seems to Me," World-Telegram, September 21 and December 29, 1932.

${ }^{66}$ Broun, Collected Edition, 287.
} 
imprisoned labor radical Tom Mooney, the Socialist Old Guard objected, prompting him to quit. "In getting out of the Socialist Party," he wrote, "one should leave by the door to the left."

By mid-1933, Stolberg and Broun were in concurrence that, "Radicalism will not grow quickly here until it is preached in the American idiom." ${ }^{68}$ Yet they reacted distinctly to the New Deal. For Stolberg, "the American Leviathan," its capitalist system, demanded "revolutionary critique." ${ }^{69}$ In Scribner's, he cast the National Recovery Administration (NRA) and its labor protections under Section 7(a) as "A Government in Search of a Labor Movement."70 Arriving at the NRA's new Washington offices, he was greeted "Hello, Ben!" right and left, by "boys and girls who had lately been clerks in the Amalgamated Clothing Workers' office in Union Square." ${ }^{71}$ The familiarity did not stop Stolberg from becoming a piercing critic of the New Deal. In The Economic Consequences of the New Deal, coauthored with housing official Warren Jay Vinton and published in early 1935, he interpreted it as a socialdemocratic half-measure that eschewed bank nationalization, left "monopoly capitalism" intact, and created the NRA, "a cartelizing outfit with price-fixing tendencies and humanitarian cant." Restricting production to restore prices by scarcity would magnify, not resolve, capitalism's intrinsic faults: "There is nothing the New Deal has so far done that could not have been done better by an earthquake." Equally stunted were the "labor oligarchy" and its "business unionism": "Its business is to corner craft skill through craft organization; to control its market through union recognition; and to sell its labor on the best possible terms through collective bargaining." ${ }^{72}$

Broun, conversely, welcomed the NRA as "the first immediate attempt to take the depression in any way but lying down. ${ }^{\prime 73}$ In the newspaper industry, Pulitzer's closure of The World in 1931 and the

\footnotetext{
67 "It Seems to Me," World-Telegram, April 29, 1933.

${ }^{68}$ Broun, "All Quiet Along the Rubicon," 5.

${ }^{69}$ Stolberg, "Votes Won't Do It!" 12.

${ }^{70}$ Stolberg, "A Government in Search of a Labor Movement."

${ }^{71}$ Adamic, My America, 79.

72 Stolberg and Vinton, Economic Consequences of the New Deal, 33, 51, 54, 85.

73 "It Seems to Me," World-Telegram, September 18, 1933.
} 
economic crisis had created pervasive anxiety, and Broun sensed that Section 7(a) presented a chance to do something about it. Reporters' wages had been slashed by a third or more, much worse than the better-paid and union-protected printers and pressmen. Broun deemed it time for a newspaper writers' union: "Beginning at nine o'clock on the morning of October $1 \mathrm{I}$ am going to do the best I can to help in getting one up. I think I could die happy on the opening day of the general strike if I had the privilege of watching Walter Lippmann heave half a brick through a Tribune window at a non-union operative who had been called in to write the current 'Today and Tomorrow' column on the gold standard." Four meetings took place in the messy study of Broun's penthouse on West 58th Street, then three hundred met at the City Club in September, and by December the founding convention of the American Newspaper Guild met in Washington, unanimously electing Broun president, a post he retained for life, never taking a salary. On all of the Guild's key strategic issues-whether to be a labor union or professional association, whether to join the AFL (or later $\mathrm{ClO}$ ), and whether to admit office staff or stick solely to news and editorial departments-Broun championed the left position, holding that the Guild should be a union, inclusive and industrial. He authored a forthright clause against racial discrimination. Yet Guild moderates respected his conventional success, and Broun downplayed fears of radicalism with self-deprecation about his "fatal constitutional longing toward compromise." Without Broun as its champion, the Guild would almost surely have foundered. ${ }^{74}$

As the Guild organized for a forty-hour, five-day week, salary floors, and dismissal noticessigning its first collective-bargaining contract at the Philadelphia Record-a nationwide labor upsurge materialized in 1934. "It Seems to Me" now appeared in the World-Telegram, the hyphenated title a result of Scripps-Howard absorbing the World. Broun's writing matured as he supported the New York taxi and waiters' strikes, hailed legislation to end child labor, and pilloried right-wing publisher William

\footnotetext{
${ }^{74}$ On the American Newspaper Guild's years under Broun, see especially Leab, A Union of Individuals, and Scott, "Labor's New Deal for Journalism." Citations above: Broun, Collected Edition, 297; Broun, untitled letter, 1934, Newspaper Guild of New York Records, Box 5, Folder 1a, Tamiment Library.
} 
Randolph Hearst. During the Toledo, Ohio, Auto-Lite strike, a militiaman's bayonet poked his spine, he was gassed, and state troopers detained him for being a New York Communist. "Columnist," Broun corrected. ${ }^{75}$ Defending unions as a way to raise purchasing power, he criticized strikebreakers: "The man who takes another's job is a far more despicable thief than the one who takes another's watch or wallet. But this is the sort of rogue the police are called in to protect." ${ }^{76}$ With his hulking frame perched over the typewriter, legs splayed on both sides, the tip of his tongue poking through pursed lips, Broun punched out lines rarely seen in the commercial press, condemning "the great Chinese wall called Property Rights which has been set up to keep us all away from human rights."77

Even in battle, Broun retained magnanimity. Walking a picket line at the Newark Ledger, he saw a newsman who crossed the line coming out. "Here, I would like to talk with you," he said, escorting the man to a bar across the street, where he gave him what-for, round after round. ${ }^{78}$ On July 17, 1934, Broun represented the Guild personally in its first meeting with Arthur Hays Sulzberger at the New York Times, where 224 out of seven hundred relevant employees were Guild members. Times pay and conditions met Guild objectives, Broun said, merely needing codification in a contract. "We are opposed to the union conception for news department workers," Sulzberger replied, arguing that the "closed shop" threatened freedom of the press and objectivity by imposing homogeneity. ${ }^{79}$ The Guild actually sought a "preferential shop" that would allow publishers to hire anyone so long as the employee later joined the union. Broun thought Sulzberger's worrying over uniformity of opinion "fantastic": "One evening at a meeting...should convince him that it is the Guild itself which has achieved the utopian state of compensating for all prejudices by matching one against the other." ${ }^{80}$

\footnotetext{
${ }^{75}$ Kramer, Heywood Broun, 254.

${ }^{76}$ Broun, "The Brass Knuckles of the Neutrals."

${ }^{77}$ Broun, It Seems to Me, 321.

${ }^{78}$ Kramer, Heywood Broun, 260.

${ }^{79}$ A. H. S., memorandum, July 17, 1934, New York Times Company Records, Arthur Hays Sulzberger Papers, Box 194, Folder 6, Manuscripts and Archives Division, New York Public Library.

${ }^{80}$ Broun, "Mixed Pickles."
} 
As for the New Deal, Broun had been impressed by FDR's charm when invited to the White House, and he mocked conservatives by saying that the New Deal's "dirty work" to "Sovietize America" transpired at night: "It is then that Guy Tugwell sneaks out armed with chalk and writes 'Capitalism Must Be Destroyed' on the sidewalks of the town. ${ }^{\prime 81}$ Nevertheless, by 1935 Broun was sounding something like Stolberg as he grew frustrated with the NRA for conciliating publishers in its code. By early 1935, he was calling Roosevelt "labor's Public Enemy No. 1," and saying, "There is no Santa Claus; not even in the White House." ${ }^{82} \mathrm{He}$ and Stolberg were both playing a part in the pressures-intellectual, political, labor-pushing the New Deal leftward. Yet they were also about to diverge again.

\section{The Popular Front, Communism, and the $\mathrm{ClO}$}

The year 1935 was a watershed. The New Deal moved substantially to the left with passage of the National Labor Relations Act (NLRA), the Social Security Act, and the Wealth Tax. The Communist Party announced a new People's Front alliance of liberals and the left against fascism and war. Finally, the $\mathrm{ClO}$, launched by John L. Lewis, created a bloc for industrial unionism within the AFL. To Broun, these were salutary confluences. He embraced the $\mathrm{ClO}$ through his newspaper column, a "Broun's Page" for The Nation, and, two years later, a ClO News column he undertook for $\$ 1.50$ a week. ${ }^{83}$ His closest Guild associates in New York were Communists, and he contributed a short story about newspapermen to the New Masses. ${ }^{84}$ Pivoting, Broun began describing the New Deal's advocates as "the nucleus for a true Farmer-Labor Party. ${ }^{185}$ In 1936, Broun called Roosevelt "the political genius of our age," and on Christmas Eve 1937, when the President read a column of his over the radio airwaves,

\footnotetext{
${ }^{81}$ Broun, Collected Edition, 306.

82 Broun, Collected Edition, 297; Broun, untitled letter, 1934, Newspaper Guild of New York Records, Box 5, Folder 1a, Tamiment Library; “It Seems to Me," World-Telegram, September 18, 1933; “Newspaper Guild Flays Broun for Rap at Roosevelt," Dallas Morning News, April 15, 1935; Leab, A Union of Individuals, 203.

${ }^{83}$ Harris, American Labor, 178.

${ }^{84}$ Broun, "Enduring Bronze."

${ }^{85}$ Broun, "Roosevelt Comes Up Swinging."
} 
Broun downed four drinks in quick succession and wept. ${ }^{86}$ Little wonder that Michael Gold, the Communist novelist, in reviewing a collection of Broun's columns in the New Republic, called him "a symbol...of the united front," or that a Nation editor (who happened to be one of Stolberg's lovers) said Broun "seemed to aspire to be a broad united front in his own expansive person." 87

The CIO's emergence was equally heady for Stolberg, who greeted it as a sign of a "progressive drive" within labor. ${ }^{88}$ In a three-part profile for the Nation, Stolberg called John L. Lewis "a militant opportunist in the best sense" who preferred mass organization to "bureaucratic vegetation," and cast the $\mathrm{CIO}$ as "the living, organic forces of our working class against the dead hand of Gompers, Green, Woll, and Company." ${ }^{89}$ In a pitch to Sulzberger at the Times, Stolberg conjectured that if the AFL leadership's machinations split the federation, then the ILGWU-once again the brightest star in Stolberg's firmament after David Dubinsky's organizing drive won hundreds of thousands of new members - would go with Lewis. "Personally," he wrote, "I am for the $\mathrm{ClO}$ and, to that extent, for Lewis." ${ }^{90}$ In 1936, Stolberg anticipated that if Roosevelt were re-elected, he would likely move to the right, giving space to a farmer-labor party that Lewis would back. Lewis thought Stolberg had done "extremely well" in his profiling of him: "It is always very interesting, and sometimes rather startling, to see yourself reflected in someone else's eyes." ${ }^{\prime 1}$ Stolberg and Broun might have been twins in their enthusiasm for Lewis, the $\mathrm{ClO}$, and the idea of a farmer-labor party, were it not for their incompatibility on Communism and the New Deal, each of which Stolberg still viewed skeptically.

The novelist Mary McCarthy, a secretary-typist for Stolberg at this time, recalled him as "a mine of knowledge" who "talked, snorting, through his nose," subsisted off a wealthy poetess, and "had a

\footnotetext{
${ }^{86}$ Broun, Collected Edition, 377, 445.

${ }^{87}$ Gold, "It Seems to More of Us"; Marshall, "Heywood Broun."

${ }^{88}$ Stolberg, "John L. Lewis, Portrait of a Realist," 122.

${ }^{89}$ Stolberg, "John L. Lewis, Portrait of a Realist," 124; Stolberg, "The Education of John L. Lewis," 150; Stolberg, "The Education of John L. Lewis. III," 177.

${ }^{90}$ Stolberg to Sulzberger, November 21, 1936, BSP Box 8, Folder S1.

${ }^{91}$ Lewis to Stolberg, September 4, 1936, BSP Box 1.
} 
mammoth writers' block and a genius for wasting time when he should have been working." ${ }^{92}$ However, it bears remembering, as Hemingway wrote, that, "In the newspaper business, it is such an important part of the ethics that you should never seem to be working. ${ }^{\prime 93}$ Actually, Stolberg was showing more verve and vigor than in years-most often in The Nation, where he published an exposé of anti-labor vigilantism and called the $\mathrm{ClO}$ "the most progressive and vital force in American life today." Justifying sitdowns, Stolberg considered it fanciful that those "who own our industries will yield without a desperate struggle": "Nothing but militancy ever organizes labor." ${ }^{94}$

Not only was Stolberg a seasoned labor journalist by this time, but the field was expanding as newspapers assigned reporters to the labor beat. Together with Joseph Shaplen and Louis Stark of the Times, Stolberg would sit around with Lewis in his hotel bedroom until three in the morning. He was the first to report, for example, Lewis's now-legendary phrase about how he proposed to handle Communist organizers in the CIO: "Who gets the bird, the hunter or the dog?" ${ }^{95}$ Stolberg's eye was unsparing toward his competitors. Shaplen he rated above Stark, who lacked the "suspicious and iconoclastic shrewdness" needed given that "what labor hands you officially is worthless." Mary Heaton Vorse he considered "a Communist sob sister"; when she came to him for explanations, he supplied them knowing "damn well that she would pervert it."

By 1937, Stolberg, who always followed Russian developments closely, was brooding over the Moscow trials, in which Bolshevik founders confessed to collaborating with the Nazis to undermine the Soviet regime, incriminating themselves and Leon Trotsky in absentia. Stolberg joined the Commission of Inquiry that traveled to Mexico in April 1937 to interview the exiled Russian revolutionary. The American Communist Party, seeking to discredit the effort, branded Stolberg a "well-known Trotskyite," but he

\footnotetext{
${ }_{92}$ McCarthy, Intellectual Memoirs, 31, 33.

${ }^{93}$ Hemingway, The Sun Also Rises, 11.

94 Stolberg, "The ClO Moves On," 205.

${ }^{95}$ Stolberg, "Communist Wreckers in American Labor," 6.

96 "Reminiscences."
} 
was not one; he was sui generis. Writing Freda Kirchwey, editor of The Nation, Stolberg vowed that he was "not emotionally committed" to Trotsky: "If I should become convinced that he is guilty-and with him the entire leading personnel of the October revolution - I certainly would say so." ("As an aside," Stolberg added revealingly, "an analyst told me that unfortunately I am never emotionally committed to anybody or anything.") ${ }^{97}$ Stolberg differed from Trotsky in renouncing "terror in any form, good or bad" along with the "dictatorship of the proletariat" since "all dictatorships are dictatorships of the dictatorship." 98 The questions he put to Trotsky were hardly obsequious: "Do you think that you delayed...the organization of the Left Opposition, and that that was one of the errors made? That as a diplomat you were not very good?"99 In the end, Stolberg joined with philosopher John Dewey and journalist Suzanne La Follette-a fellow habitué of the Hotel Chelsea on West 23rd Street and another of his lovers-to write Not Guilty (1938), the Commission's final report. Months of thought about Joseph Stalin's murderous purges left Stolberg deeply apprehensive about the Communist Party's increasing influence in the American labor movement.

In Broun's political geography, the crucial locus of 1937-38 was not Moscow but Madrid, where Spain's democratically elected Popular Front government was struggling, with Soviet aid, to defeat a militarist rebellion led by general Francisco Franco, supported by fascist Italy and Nazi Germany. Close enough to the Communist Party that he could write a column saying that the Daily Worker's labor coverage balanced out that of the New York Times, Broun charged that left unity was jeopardized by "Trotskyites": "those who sabotage a radical or progressive movement because some part of its policy does not meet with their complete approval." ${ }^{100}$ Various witnesses before the House Un-American Activities Committee (HUAC), launched in 1938 under conservative southern Democrat Martin Dies, vowed that Broun was a secret Communist Party member, but he denied it, testifying before HUAC, "I

\footnotetext{
${ }^{97}$ Stolberg to Freda Kirchwey, May 18, 1937, BSP Box 5, Folder K.

${ }^{98}$ Stolberg speech, Center Hotel, New York, December 12, 1937; Stolberg, "Thermidor and the Lady Giraffe," 21.

${ }^{99}$ The Case of Leon Trotsky, 430.

${ }^{100}$ Broun, "Trotskyism at Home and Abroad."
} 
am for CIO leadership and I favor the Loyalist cause in Spain. I am against fascism and I am for peace and democracy. I am not a Communist and never have been a Communist." ${ }^{101}$ Afterward, Broun named a rooster at his Connecticut farm "Martin Dies"; when the bird was plucked and cleaned, he found, it was "just fuss and feathers." 102

As the most left-liberal columnist in the country, Broun was taking risks, particularly since Scripps-Howard under publisher Roy Howard was moving rightward, reversing its once pro-labor editorial stance to resist the Newspaper Guild and New Deal, all with an eye toward the bottom line. In The Nation, Broun wrote bravely that Scripps-Howard workers "must choose between being gelded or guilded. ${ }^{\prime 103}$ After his arrest in support of the 1936 strike against Hearst's Milwaukee News, he told fellow Guild radical Carl Randau, "Roy hates me now. I can feel it." ${ }^{104}$ The World-Telegram had begun running a column on the same page as Broun's by Westbrook Pegler, a purple-prose writer who in 1938 attacked Broun for running a "rat, scab, and fink shop" at The Connecticut Nutmeg, his sideline periodical; it was true that the Nutmeg's solitary staff member did not belong to the Guild, but Broun paid better than Guild rates and the Guild did not accept one-person shops. Pegler's reactionary bile, Broun explained, was because he had been "bitten by an income tax."105

\section{Inside the $\mathrm{ClO}$}

Given that they were on opposite sides of the left's great divide, it was perhaps inevitable that Stolberg and Broun would clash. The skirmish erupted in January 1938, when the World-Telegram and the rest of the Scripps-Howard chain published a front-page, twelve-part series, "Inside the ClO," by Benjamin Stolberg. Praising the ClO for its "brains and militancy," Stolberg called it "our most important

\footnotetext{
101 Investigation of Un-American Propaganda Activities in the United States, 1: 880, 938.

102 Broun, Collected Edition, 493.

103 "Broun's Page," The Nation, August 8, 1936.

${ }^{104}$ Kramer, Heywood Broun, 275.

105 Broun, "Only a Boy"; Broun, "The Right People."
} 
social movement since the Civil War" and "of paramount democratic importance to American industry and hence to American life." Distinguishing his analysis from the rabid Hearst press, Stolberg said it was "not true" that "the CIO is radical, red, communist, socialist or what not": "More than 2,000,000...are in unions which have no political complexion of any kind or in which factionalism is negligible." However, Stolberg alleged, "one-third" of the CIO was "gravely ill," afflicted by a struggle between "progressive trade unionists" and the Communist Party, which "no doubt wants a strong labor movement, but only if it can control it." He maintained that "an economic labor organization such as the ClO cannot keep out individuals because of their political beliefs" and that "radicals always play an important part" in "every upsurge in labor," but held that in the United Auto Workers (UAW), the ClO's flagship union, Communists had fomented wildcats that violated the union's contractual commitments in order to discredit the union's anti-Communist leadership: “After the great sit-down strikes in January and February 1937, which really established the union in the industry, the Communist opposition precipitated a great many of the almost 200 unauthorized sit-downs between March and June 1937." Heywood Broun, Stolberg charged, had been "prevailed upon to attack" UAW president Homer Martin "in his syndicated column with much sarcastic innuendo," and "John L. Lewis wrote Mr. Broun, quite plainly, what he thought of such behavior."106

The penultimate article of "Inside the CIO" was on the Newspaper Guild. Prior to the Guild, Stolberg acknowledged, newspaper work paid \$38 for a 48-50 hour week, with zero job security. He granted that the "man who had most to do" with the Guild's creation was Broun, and that the union had been "amazingly successful" against "tory publishers," winning most strikes and signing "comparatively good agreements." Thereafter, the portrait was unflattering. "Felicitous but naive," Broun was "always for civil liberties until Stalinism became the most fashionable form of radicalism among the New York intelligentsia." His leadership faction favored "cocktail Communism," although the national-office

\footnotetext{
${ }^{106}$ Stolberg, "Inside the C.I.O."
} 
atmosphere was "no more 'subversive' or 'revolutionary' than at the Astor bar." Guild successes should be credited instead to a rank and file of intelligent newspaper writers "who know their publicity and who behind their hard-boiled attitude hold a great devotion to their ideals." Their victories were won, according to Stolberg, "in spite of the tactics of its national officers," such as unwise resolutions on Spain. ${ }^{107}$ (This reflected a commonplace reservation among reporters, such as a writer in Scribner's who considered passing political resolutions "highly improper" for "a gathering of newspapermen, whose job it is impartially to report the news." $)^{108}$

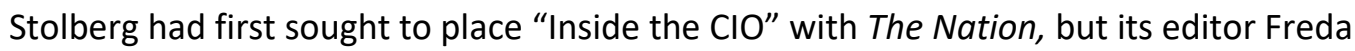
Kirchwey-a Popular Front liberal, though one who had cancelled Broun's page in 1937, causing him to move to the New Republic-urged Stolberg to "watch your step with particular caution in the article on the Communist Party, etc." because the magazine did not wish to supply "ammunition to the gang in Congress and out who are laying for the whole left-labor movement." ${ }^{109}$ When Kirchwey rejected his copy in December 1937, she held that Stolberg "described facts about Communist activity in a way that made it appear they were the major aspect of the $\mathrm{ClO}-$ a most lopsided and harmful impression to spread." Stolberg rejoined that she had eviscerated The Nation's "tradition of fearless journalism." Never again would he write for The Nation..$^{110}$

The Daily Worker attacked "Stoolberg" as a "stool-pigeon of the pen" who set "out to tear down the CIO itself" as "an agent of fascism masquerading as a 'friend of labor.' "111 In actuality Stolberg's perspective reflected sources within the CIO, particularly a bloc that included the ILGWU's Dubinsky (whose union was about to revert to the AFL), ILGWU Local 22 head Charles Zimmerman (a member of Jay Lovestone's Right Opposition of expelled Communists), and other socialists and Lovestoneites,

\footnotetext{
107 Stolberg, "Inside the C.I.O."

108 Pringle, "The Newspaper Guild," 23. A similar objection from Louis Stark is noted in Witwer, "The Heyday," 19.

${ }^{109}$ Kirchwey to Stolberg, July 28, 1937, BSP Box 6, Folder N.

${ }^{110}$ Kirchwey to Eugene Lyons, September 15, 1938, BSP Box 5, Folder K; Stolberg to Kirchwey, December 7, 1937 BSP Box 6, Folder N; "Reminiscences."

111 "Twelve Doses of Poison," Daily Worker, January 11, 1938.
} 
particularly in key UAW staff positions under Homer Martin. ${ }^{112}$ Information from this rightward-tending Dubinsky-Lovestone network led Stolberg to paint Martin, a Baptist preacher from Kansas City with whom he spent a week in Detroit, as a progressive hero although the inept Martin would soon lose the UAW presidency. ${ }^{113}$ Other news reports, including in the New York Times, blamed the post-Flint sitdowns of 1937 on Communist design, but most labor historians attribute them to the frustrations and militancy of an inexperienced rank and file. ${ }^{114}$ That said, Stolberg's articles did accurately describe the extent of Communist clout in the $\mathrm{ClO}$, from maritime to the electrical industry, and he received considerable admiring mail from workers in various Communist-led unions and independent radicals. "You have no idea what you stirred up," a Nation writer in Pittsburgh wrote him about the series. "Everybody is talking about them. As is to be expected, all the tories like them, all the commies curse them, and the liberals are worried... The more I observe the reaction to them, the more convinced I become that they were absolutely necessary."115

In the New Republic, Broun characterized Stolberg as "cleverer than many others in his skill in draping himself in sheep's clothing," but denied he could be "inside" the ClO if not a member of any of its unions. "Disliking Homer Martin is so easy that no commentator needs a nudge from Moscow," Broun wrote. Suggesting that Stolberg had "capitalized on the white-collar resentment of CIO success," he called him a "burnt-cork radical" - or, privately, a "black-face radical."116 That spring, Broun warned of new dangers to the Popular Front: "The Red-baiters are in more furious full cry right now than ever before. Liberals and progressives have joined the pack. And in doing this, whether they realize it or not,

\footnotetext{
112 Francis A. Henson to Louis Adamic, January 18, 1938, and Stolberg to G. B. Parker, January 18, 1938, BSP Box 8, Folder S1; Lou [Waldman] to Stolberg, February 1, 1938, BSP Box 8, Folder S2.

${ }^{113}$ Harris, Labor's Civil War, 136; Cochran, Labor and Communism, 130.

114 "Reds in Union Urge New Type G.M. War," New York Times, November 26, 1937; Cochran, Labor and Communism, 138; Boryczka, "Militancy and Factionalism"; Zieger, The ClO, 1935-1955, 98-100.

${ }^{115}$ Rose M. Stein to Stolberg, January 24, 1938, BSP Box 8, Folder S1.

${ }^{116}$ Broun, "Shoot the Works," New Republic, January 26, 1938; Helen [unknown surname] to Stolberg, January 20, 1938, BSP Box 8, Folder S1; Broun, "Fathers and Sons in Comic Strip."
} 
they are most distinctly playing the game of Hitler." To Broun, it was simple: "Communists are good guys and Fascists are not."117

As the Congress of Industrial Organizations was launched that November as a federation separate from the AFL, Broun spoke comically from the floor in Pittsburgh about press exaggerations of Communism, recounting that in a poker game the night before he held three kings and was sure of victory until his opponent, a newspaperman, laid down three aces: "I've seen the headlines and observed the deliberations of the Dies Committee, and so when he grabbed the pot I said, 'You dirty Red!'”118 Publication that autumn of Stolberg's book The Story of the ClO, reprising the Scripps-Howard series, prompted another Broun rebuttal in the New Republic: "Mr. Stolberg says of the Guild that it has been 'amazingly successful in improving the lot of the editorial writer.' And yet most of his chapter is spent in criticizing the union's executives. Seemingly they have lost everything but the Yale game. ...Mr. Stolberg can't even get his bars straight. It isn't the Astor. It's Jack and Charlie's."119

As the year 1939 dawned, Broun was still ardently for the Popular Front. In May, however, he confounded his admirers by converting to Catholicism. It should not have been a shock. Biblical allusion long suffused his prose, whether in accusing strikebreakers of seeking "a few meager and immediate pieces of silver" or reckoning that Cain ("Am I my brother's keeper?") had "first voiced and set the philosophy of isolation and rugged individualism." Defending his faith despite Church support for Franco, Broun observed that "a very heavy proportion of both the membership and the leadership of $\mathrm{CIO}$ is Catholic" and held out for "collective bargaining even at Final Judgment."120 In September's Saturday Evening Post, Stolberg still accused Broun of holding "to the 'party line,' discreetly in his newspaper column, wildly in his weekly page in the New Republic, a Stalinoid 'journal of liberal opinion,'

\footnotetext{
${ }^{117}$ Broun, "How Not to Get Tough About It."

${ }^{118}$ Proceedings of the First Constitutional Convention, 215.

119 Broun, "Dictated But Not Red."

${ }^{120}$ Broun, Collected Edition, 317, 423.
} 
and unscrupulously in the Newspaper Guild." ${ }^{121}$ Even before those words hit newsstands, though, the Nazi-Soviet pact changed everything. The pact hardly negated the validity of labor unions or the New Deal, noted Broun, nor did it prove Communists wrong on unemployment or Scottsboro, but the jettisoning of the great democratic alliance against fascism dismayed him, and he now distanced himself from the Party: "The weakness of communism has always been in its basic dependence upon leadership which was far away and unfamiliar with American conditions."122 In a Herald-Tribune series on Communism's crisis, Stolberg crowed, "The first casualty among the individual fellow-travelers was Heywood Broun, who fell off the Stalinist band-wagon immediately after the trade pact was announced, and has stayed off."123 Broun for his part, having been elected six times unanimously to head the American Newspaper Guild, continued to see Stolberg as merely an annoying interloper: "Nor do I understand at all by what process Stalin's diplomacy has suddenly justified the assertion of Ben Stolberg that he, Benjamin, is a friend of labor."124 Broun's main problem, in any event, was not Stolberg. That autumn, Roy Howard declined to renew Broun's contract, forcing him to accept a New York Post offer at one-quarter the salary. Only one desultory column of Broun's appeared in the Post before he died; contracting a cold, he had continued his customarily heavy drinking until pneumonia set in. "I have more faith than I ever had before," he wrote earlier that year in a meditation about turning 51. "People are better than I thought they were going to be-myself included." ${ }^{125}$

Recent scholarship emphasizes that criticism of Communism was integral to organized labor, including its official redoubts, well before McCarthyism. ${ }^{126}$ Stolberg's broadside against Broun indicates that this insight deserves extension to the labor left. Broun's hatred of fascism and passion for labor led him into an alliance with the Communist Party that left him vulnerable to Stalin's foreign policy. If that

\footnotetext{
${ }^{121}$ Stolberg, "Communist Wreckers in American Labor," 32.

122 Broun, Collected Edition, 497, 525.

123 Stolberg, "Collapse of Communism in U.S."

${ }^{124}$ Broun, Collected Edition, 525.

${ }^{125}$ Broun, Collected Edition, 551.

${ }^{126}$ Luff, Commonsense Anticommunism.
} 
vindicated Stolberg, Broun would have found his own suspicions confirmed had he lived another dozen years, for Stolberg first became a supporter of the AFL leadership, and then a conservative Republican, falling victim along the way to debilitating writers' block. Heywood Broun once doubted he could ever be a "good newspaperman" because "there are almost no situations in which I am neutral by the widest stretch of the imagination." ${ }^{127}$ The Times-promulgated doctrine that journalistic objectivity requires neutrality or "balance" certainly did not fit him-or Benjamin Stolberg. Their journalism was vigorous because it took stands. Despite their antipathy, both Broun and Stolberg exemplified the promise and perils of socially committed journalism. They offered interpretations contrary to negative press framings of labor as violent, subversive, or crime-ridden. They sometimes erred, but in tacking between the liberal weeklies and an increasingly conglomerated newspaper industry they managed to write with conviction, insight, humor, and humanity. Their work deserves remembrance, just as Broun eulogized Pulitzer's World: "Some part of stuff set down on paper was you, and ever will be." ${ }^{128}$

\footnotetext{
${ }^{127}$ Broun, Collected Edition, 397.
}

${ }^{128}$ Broun, Collected Edition, 254. 


\section{BIBLIOGRAPHY}

Adamic, Louis. 1938. My America. New York: Harper and Bros.

Adams, Franklin P. 1930. "Comrade Broun." The Nation, October 1.

Bernstein, Irving. 1960. The Lean Years: A History of the American Worker, 1922-1933. Boston: Houghton Mifflin.

Boryczka, Ray. 1977. "Militancy and Factionalism in the United Auto Workers Union, 1937-1941," Maryland Historian. 8: 13-25.

Broun, Heywood. 1933. "All Quiet Along the Rubicon." Common Sense, 2, no. 1: 4-5.

-. 1935. "The Brass Knuckles of the Neutrals." The Nation, April 3.

-. 1935. "Enduring Bronze." New Masses, 17, no. 19: 20-21.

-. 1935. "Mixed Pickles." The Nation, October 2.

-. 1935. It Seems to Me, 1925-1935. New York: Harcourt, Brace.

—. 1936. "Roosevelt Comes Up Swinging." The Nation, July 4.

-. 1937. "The Right People." The New Republic, September 29.

-. 1937. "Trotskyism at Home and Abroad." The New Republic, March 23.

-. 1938. "Dictated But Not Red," The New Republic, November 2.

-. 1938. "Fathers and Sons in Comic Strip." The New Republic, February 9.

-. 1938. "How Not to Get Tough About It." The New Republic, March 30.

-. 1938. "Only a Boy." The New Republic, August 17.

-. 1941. Collected Edition of Heywood Broun, ed. Heywood Hale Broun. New York: Harcourt, Brace. Browder, Earl. 1923. "Our Timid Progressives." Labor Herald, April.

-. 1924. "Workers' Education-or Mis-Education?" Labor Herald, July.

-. 1925. "The Predicament of American 'Intellectuals.' " Daily Worker, October 3.

Cochran, Bert. 1977. Labor and Communism. Princeton: Princeton University Press.

Committee on Un-American Activities, House of Representatives. 1938-39. Investigation of UnAmerican Propaganda Activities in the United States. Washington, D.C.: U.S. Government Printing Office.

Dubinsky, David, and A. H. Raskin. 1977. David Dubinsky: A Life with Labor. New York: Simon and Schuster.

Ernst, Morris L. 1947. The Best is Yet. London: Penguin.

Garlin, Sender. 1929. "Fake 'Progressives' Discuss the U.S. Labor Movement." Daily Worker, March 4.

Gitlow, Benjamin. 1940. I Confess. New York: E. P. Dutton.

Gold, Michael. 1935. "It Seems to More of Us," The New Republic, October 23.

Harris, Herbert. 1938. American Labor. New Haven: Yale.

Hemingway, Ernest. 1986. [1926] The Sun Also Rises. New York: Collier

Ickes, Harold. 1939. America's House of Lords: An Inquiry into the Freedom of the Press. New York: Harcourt, Brace.

Kramer, Dale. Heywood Broun. 1949. New York: Current.

Laidler, Harry, and Norman Thomas, eds. 1926. New Tactics in Social Conflict. New York: Vanguard.

Leab, Daniel. 1970. A Union of Individuals: The Formation of the American Newspaper Guild, 19331936. New York: Columbia.

Luff, Jennifer. Commonsense Anticommunism: Labor and Civil Liberties Between the World Wars. Chapel Hill: University of North Carolina, 2012.

Marshall, Margaret. 1938. "Heywood Broun," The Nation, May 21.

McCarthy, Mary. 1992. Intellectual Memoirs: New York, 1936-1938. New York: Harcourt Brace Jovanovitch.

O'Connor, Richard. 1975. Heywood Broun. New York: G. P. Putnam's. 
Parmet, Robert D. 2005. The Master of Seventh Avenue: David Dubinsky and the American Labor

Movement. New York: New York University.

Pringle, Henry F. 1939. "The Newspaper Guild." Scribner's, January.

Proceedings of the First Constitutional Convention of the Congress of Industrial Organizations, Pittsburgh, Pennsylvania, November 14-18, 1938.

Rondinone, Troy. 2010. The Great Industrial War: Framing Class Conflict in the Media, 1865-1950. New Brunswick: Rutgers.

Scott, Dale Benjamin. "Labor's New Deal for Journalism - The Newspaper Guild in the 1930s." Ph.D. University of Illinois at Champaign, 2009.

Seldes, George. 1987. Witness to a Century. New York: Ballantine.

Stark, Louis. 1942. "The Press and Labor News." Annals of the American Academy of Political and Social Science, 219: 107-113.

Stewart, Kenneth. 1943. News is What We Make It: A Running Story of the Working Press. Boston: Houghton Mifflin.

Stolberg, Benjamin. 1919. "Prof. Kallen on Class Warfare." Chicago Evening Post, February 7.

-. 1921. "The Kansas Industrial Court," The Federated Press, February 24 and 28.

-. 1922. "The Great Stupidity: The Story of the Labor Board's Strike." Labor Age, 11, no. 9: 18-21.

-. 1922. "The Tragedy of Coal." The Nation, March 22.

-. 1922. "The Vanguard." The Survey, May 20.

-. 1923. "Diverging Paths on Labor's Highway." New York World, August 19.

-. 1923. "Railroad Labor Amalgamation." New Republic, February 21.

-. 1923. "Railroad Labor's Tendencies." New York Post, August 16.

-. 1923. "The Revolt in the Unions," The Nation, June 25.

-. 1924. "Beginning the Great Change in Industry, Labor Unions, Assuming Responsibility, Show Capital How to Solve Its Problems." New York World, October 5.

-. 1924. "The Mouse That Frightens Hughes." Hearst's International, March.

-. 1924. "The Shake-Up of the World Is Rousing Women to Action." New York World, April 13.

-. 1925. "A Great Journalist." The New Leader, July 18.

-. 1925. "The End of the Gompers Tradition: A New Drift in the American Federation of Labor." The Independent, February 14.

-. 1925. "The Peter Pans of Communism." The Century, June.

-. 1925. "The Predicament of American Labor." The Nation, September 30.

-. 1925. "The Vagaries of Communism." Commonweal, December 30.

-. 1926. "Labor Action Varies in Different Lands." New York Times, September 26.

-. 1926. "The New Unionism." The Modern Quarterly, 3, no. 4: 292-300.

-. 1926. "The Man Behind the 'Times."' The Atlantic Monthly. December.

-. 1926. "The Pullman Peon: A Study in Industrial Race Exploitation." The Nation, April 7.

-. 1926. "William Green's Convention." The Nation, November 3.

-. 1927. "The Collapse of the Needle Trades." The Nation, May 4, 11, and 18.

-. 1928. "Pot Calls the Kettle Black." New Leader, January 28, 1928.

-. 1928. "The Tailor and the Scientific Method." The Nation, June 13.

-. 1933. "Votes Won't Do It!" Common Sense, 1, no. 5: 11-12.

-. 1934. "Morris Hillquit." American Mercury, 33, no. 129: 122-123.

-. 1936. "The Education of John L. Lewis." The Nation, August 8.

-. 1936. "The Education of John L. Lewis III." The Nation, August 15.

-. 1936. "John L. Lewis, Portrait of a Realist." The Nation, August 1.

-. 1937. "The ClO Moves On." The Nation, February 20. 
-. 1938. "Inside the C.I.O." New York World-Telegram, January 10, 1938, and eleven subsequent issues.

-. 1938. "Thermidor and the Lady Giraffe." Common Sense, 7, no. 1: 21-22.

-. 1938. "Was the Bolshevik Revolution a Failure?" Modern Quarterly, 11, no 1: 13.

-. 1939. "Collapse of Communism in U.S." Herald Tribune, November 26, 1939, and five subsequent issues.

-. 1939. "Communist Wreckers in American Labor." Saturday Evening Post, 212, no. 10: 5-7, 32-36.

Stolberg, Benjamin, and Warren Jay Vinton. 1935. The Economic Consequences of the New Deal. New York: Harcourt, Brace.

Stolberg, Mary M. "No Man is an Orphan in America: The Education of Benjamin Stolberg." Unpublished mss. May 1986.

The Case of Leon Trotsky. 1937. New York: Harper and Brothers.

Witwer, David. "The Heyday of the Labor Beat." Labor: Studies in Working-Class History of the Americas, 10, no. 2: 9-29.

Zieger, Robert H. 1995. The CIO, 1935-1955. Chapel Hill: University of North Carolina. 